\title{
Case law report - BACK TO THE FUTURE: Hinton v Donaldson, Wood and Meurose (Court of Session, Scotland, 28th July, 1773)
}

\author{
Iain G. Mitchell $Q C^{a}$ \\ (a) Chairman, Scottish Society for Computers and Law; \\ Chairman, Scottish Lawyers' European Group; Chairman, \\ Faculty of Advocates IT Group; Lecturer, Honorary Board of \\ Lecturers, Institut für Informations-, Telekommunikations- und \\ Medienrecht, Westfälische Wilhelms- Universtät, Münster: \\ Freeman, Worshipful Company of Information Technologists.
}

DOI: $\underline{10.5033 / \text { ifosslr.v1i2.23 }}$

\begin{abstract}
History moves in cycles, and recent debate around the extent and term of copyright is no exception to this rule. There are two forces at play, one being the view that knowledge is of value and indeed belongs to all mankind, and the other being that knowledge, as a creation of individuals, is property to be regulated and shared according to the wishes of its owner. This case law report examines the debate through a different lens, moving back from software and the Internet in favour of Stackhouse's History of the Holy Bible, Scottish printers and the year 1773 .
\end{abstract}

\section{Keywords}

Law; information technology; Free and Open Source Software; Scotland; copyright

\section{Info}

This item is part of the Case law reports section of IFOSS L. Rev.

For more information, please consult the relevant section policies statement. This article has been independently peer-reviewed.

\section{Introduction}

Human nature does not change, but what new technology does achieve is to create a new milieu in which the battles of the past can come back to haunt us in new guise. Because of the new technology, the issues can seem very new, but often what lies behind them is as old as the hills.

Take, for example, the battle which has raged for years over copyright term extensions, DRM as a means to try to control access to content which may, itself, have passed into the public domain, and the turf wars between copyright and copyleft. What lies at the back of all of this is, arguably, a conflict of values.

On the one hand, there is the value that all knowledge, all ideas are the patrimony of mankind, and they can and should be free. 
On the other hand there is the equally deeply held value of property: "what is mine is mine".

What sets up that conflict is the very idea of Intellectual Property itself: the trick of copyright was, in essence, to commoditise, if not ideas, then, at least, the expression of ideas. Section 1 of the Copyright, Designs and Patents Act 1988 provides:

"Copyright is a property right which subsists in accordance with this Part in the following descriptions of work-

(a) original literary, dramatic, musical or artistic works,

(b) sound recordings, films, broadcasts or cable programmes, and

(c) the typographical arrangement of published editions."1

That is the key to the whole concept of intellectual property: it is property ${ }^{2}$. Property is valuable: it can be rented out, it can be bought and sold, (or, to use the familiar term in the law of incorporeal movables, it can be assigned). In short, it becomes a commodity.

And so, there is set up what can be a fundamental conflict of values: on the one hand, a common patrimony which should be free, and, on the other hand, private property which can be immensely valuable to its owner.

This battle is played out every day in a society where the IP owners try to persuade an increasingly deaf public that the downloading of file-shared music and other copying of content is theft and, though, as the warnings on every DVD used to tell us:

"You wouldn't steal a car. You wouldn't steal a handbag. You wouldn't steal a television. You wouldn't steal a movie. Downloading pirated films is stealing. Stealing is against the law. Piracy: It's a crime","

the zeitgeist would seem to see nothing wrong in unrestricted copying and file sharing.

It was the genius of the invention of copyright and other forms of intellectual property that there is set up a Faustian bargain between the State and the author or creator (or, in any event, the first owner of the copyright, which, thanks to the essentially commercial nature of the concept, may well not actually be the author himself) that there is granted, in effect, a monopoly for a fixed term, during which the author can make his money, but at the end of that term, his work passes into the public domain and becomes part of the common patrimony. But, no sooner is that bargain set up than people want to renegotiate it: on the one hand those who wish to see the enlargement of the public domain, and, on the other hand, those who want to go on exploiting their property. In the middle, there may be a dispassionate debate about how best to balance these competing interests,

1 Copyright, Designs and Patents Act 1988, S1. Available at: http://www.opsi.gov.uk/acts/acts1988/UKpga_19880048 en_1.htm. Unofficial consolidated version available at: http://www.ipo.gov.uk/cdpact1988.pdf

2 The characterization of intellectual property as property, and not (as in the Napoleonic system) an emanation of the person is mandated by the Act. The philosophical basis of intellectual property in the Common Law jurisdictions is clearly as a property right. The Copyright, Designs and Patents Act is a direct linear successor of the Statute of Anne (as to which, see below) and it was that statute which, in effect, invented Intellectual Property. Thus, it is understandable why, in the Common Law jurisdictions, the nature of Intellectual Property as property seldom comes into question, and may, in part, explain why, notwithstanding the different philosophical approach of the Napoleonic systems, those systems are increasingly coming to reflect an economic model where Intellectual Property is sought to be exploited. It may also explain why International Agreements, such as the WIPO treaties, reflect a strong bias in favour of property rights. It is little wonder that, whatever continental legal systems may say, entrepreneurs the world over are attracted to the proprietary model.

3 See "Piracy: It's A Crime" advertisement, video available online at: $h \mathrm{htp}: / / \mathrm{www}$.youtube.com/watch? $\mathrm{v}=\mathrm{iPcHhOBd}-\mathrm{hl}$ 
BACK TO THE FUTURE: Hinton v Donaldson, Wood and Meurose (Court of Session, Scotland, 28th July, 1773)

but that should not blind us to the fundamental tension which lies beneath, which is there and which will never go away.

In that tension, the rightsholders can often come off best. It is relatively easy to demonstrate the value of the property on the basis of the income it generates - more difficult by far to ascribe a value to the public domain ${ }^{4}$. So, in a debate conducted on purely economic terms, the rightsholders have a clear advantage. Thus, a proper debate requires also broader social and philosophical issues to be addressed. Yet, even in such a broader debate, the tension is still there: especially when the rightsholders see their property rights in absolute terms.

This has been played out before the United States Congress more than once. Jack Valenti, President of the Motion Picture Association of America, giving testimony before a congressional committee in 1982, argued against limitations on intellectual property:

"Creative property owners must be accorded the same rights and protection resident in all other property owners in the nation."

There is, in the United States a problem with that: Article $1 \S 8$ of the United States Constitution provides:

"he Congress shall have Power...To promote the Progress of Science and
useful Arts, by securing for limited Times ${ }^{6}$ to Authors and Inventors the
exclusive Right to their respective Writings and Discoveries."

Nothing daunted, in the hearings on the Sonny Bono Copyright Term Extension Act, Congresswoman Mary Bono stated:

"Actually, Sonny wanted the term of copyright protection to last forever. I am informed by staff that such a change would violate the Constitution. I invite all of you to work with me to strengthen our copyright laws in all of the ways available to us. As you know, there is also Jack Valenti's proposal for term to last forever less one day. Perhaps the Committee may look at that next Congress." ${ }^{77}$

And so the battle rages on, through WIPO Treaties, European Directives, the DMCA, all played out in the fora of politics, the courts, by campaigners, by industry lobbyists and by lawyers: the money battles the ideals.

We've never known anything like it before, or have we?

\section{Back to the Future}

Once upon a time, in England, the members of the Stationers' Company enjoyed a monopoly on the printing of books, granted to them by Queen Mary in 1557. They would buy a manuscript from an author, and once printed, would enjoy a perpetual monopoly in the printing of the work. The

4 Although some have tried - Rufus Pollock is probably the best known: http://www.rufuspollock.org/economics/papers/value of public domain.ippr.pdf

5 Home Recording of Copyright Works: Hearings on H. R. 4783, H. R. 4794, H. R. 4808, H. R. 5250, H. R. 5488 and H. R.5705, before the Subcommittee on Courts, Civil Liberties, and the Administration of Justice of the Committee on the Judiciary of the House of Representatives, 97th Congress, 2nd Session (1982): 65 (testimony of Jack Valenti).

6 Emphasis supplied

7 Hearings on Sonny Bono Copyright Term Extension Act, House of Representatives, 7th October, 1998. Congressional Record, Vol. 144 page H9951. 
authors received no further reward; nor could authors become members of the Stationers' Company, neatly excluding them from any chance of participation in the income stream.

This monopoly finally expired in England in 1695; there was never any similar monopoly in Scotland.

After the Union of Scotland and England, the Parliament of Great Britain passed the Statute of Anne $1709^{8}$ the Long Title of which is An Act for the Encouragement of Learning, by vesting the Copies of Printed Books in the Authors or Purchasers of such Copies, during the Times therein mentioned. The preamble narrates the evil which the Act sets out to address:

\begin{abstract}
"Whereas Printers, Booksellers, and other Persons, have of late frequently taken the Liberty of Printing, Reprinting, and Publishing, or causing to be Printed, Reprinted, and Published Books, and other Writings, without the Consent of the Authors or Proprietors of such Books and Writings, to their very great Detriment, and too often to the Ruin of them and their Families: For Preventing therefore such Practices for the future, and for the Encouragement of Learned Men to Compose and Write useful Books; May it please Your Majesty, that it may be Enacted, and be it Enacted...."
\end{abstract}

The Act provided that, in respect of books existing at the date of commencement of the Act, there was granted to the authors of those books (and booksellers who had bought existing books from their authors): "the sole Right and Liberty of Printing such Book and Books for the Term of One and Twenty Years", and, to authors of books yet to be written, a similar right and liberty for an initial period of fourteen years, with (if still alive at the end of that term) an additional fourteen year term.

The Act provided for penalties against those who infringed the right (including a fine, payment to the owner of the right, and forfeiture and destruction of offending copies).

There are some noteworthy features of the regime, not least the shift of power from booksellers to authors and the provision of a mechanism for the setting of a reasonable sale price in circumstances where it is recognised that a bookseller was asking an excessive and unreasonable price for a book. In this provision, we see an acknowledgement by the legislature of the potential evils of a monopoly and an attempt to ameliorate them.

Although the right was known from the beginning as "copyright" it is not copyright as we know it, being, rather, a monopoly on the printing of certain books, which, of course, has inherent therein the right to stop others printing those books.

Pause a moment, and consider the parallels between the eighteenth century experience and the present day: first, there was a concentration of economic power in the entertainment industry (granted, London publishers and not Hollywood moguls, but that is just a function of changing technology) rather than the creators; second, that power was both expressed through and reinforced by control of distribution and was driven by a focus on technology - it is easier to print a book than it is to copy it by hand, and it is impossible to control what the buyer does with a printed book once it is in his possession - the parallels with digital rights management are obvious; and, third, there is legislative intervention, but here the parallels with today break down, for the legislation is seen as being directed against the economically powerful media industry and in

8 An Act for the Encouragement of Learning, by vesting the Copies of Printed Books in the Authors or purchasers of such Copies, during the Times therein mentioned (8 Anne c 19) - a facsimile and transcription can be found at http://www.copyrighthistory.com/anne.html 
BACK TO THE FUTURE: Hinton v Donaldson, Wood and Meurose (Court of Session, Scotland, 28th July, 1773)

favour of the perceived temporary benefit of creators and the long term benefit of society as a whole.

\section{A Preliminary Skirmish}

The booksellers were not happy at this threat to their comfortable monopoly. They had a number of very profitable books, which had, however, under the Statute of Anne, inconveniently passed out copyright. Competitors were taking it upon themselves to print competing editions. Perhaps because the parliamentary lobbying industry was not what it is today, or perhaps because none of these publications featured an anthropomorphic mouse, the booksellers' target was not to try to get the legislature to extend the term of copyright; rather, as the entertainment industry might wish it could do today, they went running off to Court with their sights set on something altogether more lucrative: getting the courts to declare that there was a common law right of copyright, which (as in Sonny Bono's fantasy) is perpetual.

The test case concerned James Thomson's poem "The Seasons", the perpetual common law copyright in which, it was claimed, belonged to one Andrew Millar, who, in the Court of King's Bench in England, sued Robert Taylor for breach of copyright ${ }^{9}$. This notion of perpetual copyright was accepted by the Court on a majority decision of three to one, the leading judgement being delivered by Lord Mansfied ${ }^{10}$ who, when he had been a barrister, had acted for the booksellers.

The dead hand of the bookseller's monopoly descended upon England, and, indeed, shortly thereafter, the Booksellers obtained an injunction in Donaldson v Beckett to prevent the reprinting of the same poem; but, of course, what an English Court says to be the law of England, is not binding upon a Scottish Court in determining the law of Scotland. The reprint industry continued to flourish in Scotland, about which jurisdiction the London Booksellers felt much as Hollywood does today about China, or (amusingly) Canada, even using the term "pirates" to describe those who printed books in breach of the claimed copyright.

So, enter one James Hinton, the Jack Valenti of his day, who joined battle in Scotland over one of his particularly profitable, and statutory copyright expired publications: Stackhouse's History of the Holy Bible $e^{11}$, which was being reprinted by Alexander Donaldson and John Wood, Booksellers in Edinburgh and James Meurose, bookseller in Kilmarnock. Armed with the sword of the decision in Millar v Taylor, Hinton sued Donaldson, Wood and Meurose in the Court of Session for declarator, interdict and damages in respect of breach of copyright.

However, Donaldson had a formidable friend and ally in the Scottish Advocate, James Boswell, whose reputation today rests almost entirely upon his biography of that great man of letters and lexicographer, Dr Samuel Johnson. But in his day, Boswell was associated with a number of highprofile cases in the cause of liberty ${ }^{12}$. Boswell was amongst those who appeared for the defence.

9 Millar v. Taylor, 4 Burr. 2303, 98 Eng. Rep. 201 (K.B. 1769)

10 In view of the main subject of the present article, there is a delicious irony in the fact that Lord Mansfield, though a distinguished English lawyer, was Scottish and shares with the present author the distinction of having attended school in Perth.

11 Or, to give it its snappy full title: A New History of the Holy Bible from the Beginning of the World to the Establishment of Christianity, with Answers to most of the controverted Questions, Dissertations on the most remarkable Passages, and a Connection of Profane History all along; to which are added, Notes explaining the difficult Texts, rectifying Mistranslations, and reconciling seeming Contradictions: The whole illustrated with proper Maps and Sculptures.

12 For example, in 1777 he assisted the runaway slave, Joseph Knight, in his successful legal case in the Court of Session against his master, John Wedderburn of Ballendean, in which Lord Kames, delivering the leading judgement ringingly declared that 'we sit here to enforce right not to enforce wrong'. (Knight v Wedderburn (1778) Mor 14545) 
The decision in Hinton $v$ Donaldson is only telegraphically reported in the law reports ${ }^{13}$, but Boswell himself published a full report, containing the complete written judgements ${ }^{14}$, the full text of which is available online at the IFOSS L. Rev. web site ${ }^{15}$.

\section{Hinton v Donaldson}

By a majority of eleven to one, the judges decided that there was no common law right of copyright in Scotland. What is especially illuminating for a modern reader is the reasoning in their respective judgements.

Certain common threads run through the judgements: the acknowledgement that, although the judgement of the English Court deserves respect, it cannot tie the hands of the Court of Session; an examination of just what the Statute of Anne achieved; and a consideration of whether a perpetual proprietorship in literary works was conform to the law of nature, or, as a modern lawyer might put it, consistent with principle. In considering that last question, although the judges did look at economic issues, this was in the context of the sort of wider debate looking at underlying social and philosophical issues which is so needed today but which so often does not happen ${ }^{16}$. A lot of what they said remains both relevant and pertinent today.

Lord Kennet's view was that there was no basis for copyright in the law of nature: rather, it was "only such a kind of right as particular states have, in some instances, conferred by a patent or privilegium for a limited time".

Lord Auchinleck also saw the limited monopoly as an exercise of the prerogative power of the crown and saw no basis in common law for a perpetual right of copyright. The sense of the primacy of the public domain comes over strongly in his Opinion:

"If a man throws out a thing in company, whether instructive or entertaining, can he maintain that he has a right of property in this bon mot to him and his heirs for ever?

"And here I beg leave to say, unless it can be shewn there is a right of property in what a person utters verbally, there can be none in what he publishes to all mankind by printing it. Indeed, when a man publishes his thoughts, he gives them away still more than the man who utters them in conversation. The latter gives them only to his hearers; but the former to the whole habitable earth."

Lord Hailes found no trace in the common law of the claimed right. He was particularly scathing of the London Booksellers, the Sages of St. Paul's Church-yard:

"The doctrine of these sages is commodious: they limit or enlarge this common-law right as best suits their own conveniency."

And he points up their hypocrisy, noting that what they were in effect claiming was:

13 Hinton $v$ Donaldson (1773) Mor 8307

14 The Decision of the Court of Session upon the Question of Literary Property; in the cause John Hinton of London, Bookseller, Pursuer against Alexander Donaldson and John Wood, Booksellers in Edinburgh, and James Meurose, Bookseller in Kilmarnock, Defenders (Pub: Boswell, Edinburgh, 1774)

15 http://www.ifosslr.org/public/hinton-donaldson-resources.html

16 As discussed above, the arguments today tend to be almost entirely economic, giving an inbuilt advantage in the debate to the rightsholders, especially where the income stream is seen to be attractive to government as source of taxation revenue. 
"...it would be hard that any one should steal from me, what I have stollen from others."

The sole dissenting judge, Lord Monboddo, though dismissive of the notion of property in ideas, was, however, persuaded that:

\begin{abstract}
"The common law of Scotland and of England, must, I think, be the same in this case, as the common law of both is founded upon common sense and the principles of natural justice, which require that a man should enjoy the fruits of his labours".
\end{abstract}

He sees this as the rationale of the Statute of Anne, but seems to have made the intuitive leap that it should also be the common law, and should apply in perpetuity. In effect, he sees property rights as having primacy, though, since the history of copyright is about the balancing and reconciling of the competing principles of public domain and private property, just where to strike that balance is what we should, today, describe as a "judgement call" and that was a call which he was entitled to make; but it is significant that, of these judges, speaking from the heart of the Scottish Enlightenment, the only one who was prepared to vote for primacy of private property was Lord Monboddo. It may be, however, that in reaching his view, he was unduly influenced by the romantic image of the poor starving author, rather than the economic reality of the wealthy publisher:

"I think it would be very hard and much to the discouragement of literature if an author, after spending a laborious life in composing a book, did not provide by it, not only for himself, but also for his family: nor is the remedy in the statute against this evil sufficient; for, the best books may be twenty years published, without having their merit known, and afterwards have a great and universal sale."

The reasoning of the Lord Justice Clerk was substantially similar to the reasoning of his brethren: the statute of Anne grants a privilege, but there is no basis in the common law for the claimed perpetual right:

"For it is certain, that neither Homer, nor Virgil, nor Chaucer, nor Spencer, had any idea, that, after they had published their works to the world, they, and their heirs and assigns, retained this property, this exclusive right of transcribing, or re-printing their works for ever.

\begin{abstract}
"In short, upon examination it will be found, that there is no foundation for this copyright in authors, in the common principles of law, and that the only ground for it is this, that, from the love of knowledge, and the admiration of the works of learning and genius, mankind are prone to give authors, not only the merit, but the reward that is due to them for their works; and upon this principle every civilized state in modern times has introduced exclusive privileges to authors, in the publication of their own works, some for a longer, some for a shorter time. But this suggests no idea of an original property in the author; on the contrary, it is inconsistent with it..."
\end{abstract}

At the heart of this lies the moral argument that copyright is a limited privilege given by a civilised state to authors; it is not a right to be taken. At the jurisprudential level, that analysis does not altogether hold up today, at any rate in the Common Law systems where the law has moved towards seeing intellectual property as, indeed, property (albeit existing for a limited period only); but at the moral level, the analysis is as true as it ever was: this right of property does not exist inherently, but only because society has chosen to give it, to carve it out of the public domain. 
Perhaps if the legislators to whom the lobbying efforts of the entertainment industry were directed were to bear that thought in mind, they would see more clearly the true balancing exercise which they are called upon to perform.

Lord Gardenston was likewise of the view that:

"...authors have in reason and equity a right to be protected in the sole and exclusive publication of their own works for a limited time. But the nature of the thing, and the practice of nations admits not of a real and perpetual property."

A substantial part of his lengthy Opinion is devoted to pouring scorn on the very idea of property in literary works. For example, he advances the picturesque argument that theft of all other property is gainful, but that theft of literary property, if it exists, is a "perilous theft by the nature of it", as "many a publication is attended with loss":

"...it would be but petty larceny; at worst, in a very few, the most aggravated and capital crime. - Who steals from common authors, steals trash; but he who steals from a Spencer, a Shakespeare, or a Milton, steals the fire of heaven, and the most precious gifts of nature. - So we must have new statutes to regulate those literary felonies."

The irony is ratcheted up further when, having stated that, on that argument, quotation is literary theft, he refers to "the author of a book called The Elements of Criticism" (who was, in fact his fellow judge, Lord Kames), whom he had always believed to be:

"an ingenious man, and a very honest gentleman; but in this view of the matter, he lies under a very criminal charge; every page of his book is enriched with quotations from the most classical poets and other authors."

Modern judges are less given to sarcasm, but the point that is so colourfully made is a serious one, which remains valid today: if there is to be perpetual property in literary works, civilised society, with its apparatus of criticism and discourse, would not be able to function; and the domain of public discourse would be swallowed up in private property, lawsuits and prosecutions. Perhaps there is a lesson here for those who would seek to erode the extent of fair use rights. .

Lord Coalston's judgement drew heavily on the idea that property had to be corporeal, or, if incorporeal, be in a corporeal thing - an analysis which may well not stand close scrutiny today; but, significantly, there is also a keen sense of the public domain - "the necessary consequence of publication is to make [the work] common to all mankind", and, later, he warns against the dangers of a perpetual monopoly.

Lord Alva was unable to see any trace of a perpetual right of literary property in Roman law ${ }^{17}$. Such a right did not form any part of the common law of Scotland. So far as it exists, it is a creature of statute:

"and therefore it can go no farther with us than it is carried by the statute; which I will gladly give force to, because it goes as far as, I think, justice and the encouragement of learning and industry, require. And I do not envy any other state or country, where either common law or statute may have carried it farther."

Lord President Dundas also could see no basis for a common law right of property distinct from

17 which heavily influences Scots law. 
BACK TO THE FUTURE: Hinton v Donaldson, Wood and Meurose (Court of Session, Scotland, 28th July, 1773)

the temporary right conferred by the Statute of Anne.

The most eloquent opinion was that of Lord Kames, who, as we have seen, was an author himself and who was to go on to strike the great blow for liberty in Knight $v$ Wedderburn.

His Opinion opens by underlining that the Court of Session is not bound by the decisions of the English Courts and then goes on to express the same doubt as Lord Coalston concerning property which was not itself either corporeal or in a thing which is corporeal. It is no more than a privilege or a monopoly. There is such a privilege or monopoly granted by the Statute of Anne, but it is a limited one:

"But to follow out the common law. The composer of a valuable book has great merit with respect to the public: his proper reward is approbation and praise, and he seldom fails of that reward. But what is it that intitles him to a pecuniary reward? If he be intitled, the composer of a picture, of a machine, and the inventor of every useful art, is equally intitled. Such a monopoly, so far from being founded on common law, is contradictory to the first principles of society. Why was man made a social being, but to benefit by society, and to partake of all the improvements of society in its progress toward perfection? At the same time, he was made an imitative being, in order to follow what he sees done by others. But to bestow on inventors the monopoly of their productions, would in effect counteract the designs of Providence, in making man a social and imitative being: it would be a miserable cramp upon improvements, and prevent the general use of them. Consider the plough, the loom, the spinning wheel. Would it not sound oddly, that it would be rank injustice for any man to employ these useful machines, without consent of the original inventors and those deriving right from them. At that rate, it would be in the power of the inventors to deprive mankind both of food and raiment. The gelding of cattle for food, was not known at the siege of Troy. Was the inventor entitled to a monopoly so as to bar others from gelding their cattle?"

These words look beyond copyright alone and eloquently justify why it is that patents (a development which then lay largely in the future), also require to be limited in duration, and, in these words, one sees the whole philosophical basis of Free and Open Source software: for society to function properly, there is need to share creative fruits. A perpetual monopoly would be a "miserable cramp on improvements and prevent the general use of them." The parallel with what tends to happen in the world of proprietary software is too obvious to need spelling out; and, perhaps by way of example, we might think of the strategic objectives of Microsoft in distorting the EU market through its anti-competitive practices such as the withholding of interfacing information, the bundling of browsers and the like.

Lord Kames continues:

"What shall be said of the art of printing? If the monopoly of this useful art was to be perpetual, it would be a sad case for learned men, and for the interest of learning in general: it would enhance the price of books far beyond the reach of ordinary readers. Such a monopoly would raise a fund sufficient to purchase a great kingdom. The works alone of Shakespeare, or of Milton, would be a vast estate."

And, of course, through its dominant position in providing operating systems, which are as critical to the running of computers as printing is to the publishing of books, Microsoft has traditionally commanded high prices and has "raised funds sufficient to purchase a great kingdom", or at any rate to have a great deal of influence in many kingdoms. 
Lord Kames then proceeds to consider the effect that such a right of property would have on the freedom of movement of goods:

"It is a rule in all laws, that the commerce of moveables ought to be free; and yet, according to the pursuer's doctrine, the property of moveables may be subjected to endless limitations and restrictions that hitherto have not been thought of, and would render the commerce of moveables extremely hazardous."

This, too, remains relevant. The underlying basis in the EU Treaties for the powers exercised by the European Commission both in the Café Hag case ${ }^{18}$ and in its dealings with Microsoft over that company's anti-competitive practices lay in the extent to which those large and dominant enterprises interfered with the free movement of goods and services throughout the EU.

Then, Lord Kames turned to the wider business and economic realities:

"Lastly, I shall consider a perpetual monopoly in a commercial view. The act of Queen Anne is contrived with great judgment, not only for the benefit of authors, but for the benefit of learning in general. It excites men of genius to exert their talents for composition; and it multiplies books both of instruction and amusement. And when, upon expiration of the monopoly, the commerce of these books is laid open to all, their cheapness, from a concurrence of many editors, is singularly beneficial to the public. Attend, on the other hand, to the consequences of a perpetual monopoly. Like all other monopolies, it will unavoidably raise the price of good books beyond the reach of ordinary readers. They will be sold like so many valuable pictures. The sale will be confined to a few learned men who have money to spare, and to a few rich men who buy out of vanity as they buy a diamond or a fine coat. The commerce of books will be in a worse state than before printing was invented: at that time, manuscript copies might be multiplied at pleasure; but even manuscript copies would be unlawful if there were a perpetual monopoly. Fashions at the same time, are variable; and books, even the most splendid, would wear out of fashion with men of opulence, and be despised as antiquated furniture. The commerce of books would of course be at an end; for even with respect to men of taste, their number is so small, as of themselves not to afford encouragement for the most frugal edition. Thus booksellers, by grasping too much, would lose their trade altogether; and men of genius would be quite discouraged from writing, as no price can be afforded for an unfashionable commodity. In a word, I have no difficulty to maintain that a perpetual monopoly of books would prove more destructive to learning, and even to authors, than a second irruption of Goths and Vandals. And hence with assurance I infer, that a perpetual monopoly is not a branch of the common law or of the law of nature. God planted that law in our hearts for the good of society; and it is too wisely contrived to be in any case productive of mischief."

It is the way of would-be monopolists that their reach has always exceeded their grasp. By driving prices up, they limit the market. The more limited the market becomes, the less healthy it becomes, relying on a fickle base which moves on to the latest new thing, leaving in its wake orphaned works. There is not a healthy base for a vigorous market, so what is the point of creating any more? In the long run, monopolies bring contraction and decay in economic activity. To those who see this as their economic model, it is perhaps sufficient to caution them that they should be careful what they wish for, lest they get it.

18 For background, see C. Morcom, "Trademarks in the European Community after Cafe Hag II" 81 Trademark Rep. 534 (1991) pp534 - 553 
Lord Kames concludes his Opinion by underlining the wider interests of society as a higher good than the short-term profit of the economically powerful, and asserts the calling of the Court to take that wider view:

\begin{abstract}
"Our booksellers, it is true, aiming at present profit, may not think themselves much concerned about futurity. But it belongs to judges to look forward; and it deserves to be duly pondered whether the interest of literature in general ought to be sacrificed to the pecuniary interest of a few individuals. The greatest profit to them ought to be rejected, unless the monopoly be founded in common law beyond all objection: the most sanguine partizan of the booksellers will not pretend this to be the case. At the same time, it will be found, upon the strictest examination, that the profit of such a monopoly would not rise much above what is afforded by the statute. There are not many books that have so long a run as fourteen years; and the success of books upon the first publication is so uncertain, that a bookseller will give very little more for a perpetuity, than for the temporary privilege bestowed by the statute. This was foreseen by the legislature; and the privilege was wisely confined to fourteen years; a sufficient encouragement to men of genius without hurting the public interest. The best authors write for fame: the more diffused their works are, the more joy they have. The monopoly then is useful only to those who write for money or for bread, who are not always of the most dignified sort. Such writers will gain very little by the monopoly; and whatever they may gain at present, the profits will not be of long endurance; a monopoly would put a final end to the commerce of books in a few generations. And therefore, I am for dismissing this process as contrary to law, as ruinous to the public interest, and as prohibited by the statute."
\end{abstract}

Though in those remarks there is something of the disdain of the gentleman scholar for the jobbing writer, that was because Lord Kames was a product of his time. The underlying message that the courts, and, it may be suggested, the legislators, should always have before them as a critical consideration the wider good of society is a lesson which is eternal, though so often unheeded today.

\title{
5. Postscript
}

Boswell's report of Hinton v Donaldson was published in time to be cited by Donaldson's counsel in the Appeal to the House of Lords in the proceedings brought in England against him by Beckett ${ }^{19}$, where, as noted above, the lower courts had granted an injunction. Donaldson's Appeal in that case was successful, and the injunction was recalled ${ }^{20}$.

Robert Forbes, Bishop of Ross and Caithness, recorded in his journal entry for 26th February, 1774, that, when the news of Donaldson's victory in the House of Lords reached Scotland, it occasioned:

"great rejoicings in Edinburgh upon victory over literary property; bonfires and illuminations, ordered tho' by a mob, with drum and 2 fifes $^{21}$."

19 A full report is to be found in Cobbett, Parliamentary History of England, vol.. XVII./KET (London, 1806-1820) and online at: http://www.copyrighthistory.com/donaldson.html

20 The decision in Hinton v Donaldson and the subsequent English decision in the House of Lords firmly shut the door on anyone trying to argue that there is such a thing as perpetual Intellectual Property. The fact that they are never cited, nor even particularly remembered today is, paradoxically, a mark not of their irrelevance but, rather, of their magisterial importance and continuing relevance.

21 Rev. Robert Forbes, A.M., Bishop of Ross and Caithness 1746-1775, (Henry Paton, ed,) The Lyon in Mourning or a Collection of Speeches Letters Journals etc. Relative to the Affairs of Prince Charles Edward Stuart, vol. 3, p. 294, (Edinburgh, 1896) 
Perhaps we no longer live in an age when judicial decisions about copyright lead to bonfires and dancing in the streets, but if we could be confident that today's legislators would not allow themselves to be persuaded by narrow commercial interests, the promoters of which, in the words of Lord Kames, "aiming at present profit, may not think themselves much concerned about futurity" and, instead were to look forward and "duly ponder whether the interest of literature in general ought to be sacrificed to the pecuniary interest of a few individuals", then, and only then might there be cause for public rejoicing.

\begin{abstract}
About the author
Iain G. Mitchell QC is Chairman of the Scottish Society for Computers and Law; Chairman of the Scottish Lawyers' European Group; Chairman of the Faculty of Advocates IT Group; Lecturer, Honorary Board of Lecturers, Institut für Informations-, Telekommunikations- und Medienrecht, Westfälische Wilhelms- Universtät, Münster; and Freeman, Worshipful Company of Information Technologists.
\end{abstract}

\title{
Licence and Attribution
}

This paper was published in the International Free and Open Source Software Law Review, Volume 1, Issue 2 (December 2009). It originally appeared online at http://www.ifosslr.org.

This article should be cited as follows:

Mitchell QC, Iain G (2009) 'BACK TO THE FUTURE: Hinton v Donaldson, Wood and Meurose (Court of Session, Scotland, 28th July, 1773)', IFOSS L. Rev., 1(2), $111-$ 122

DOI: $10.5033 /$ ifosslr.v1i2.23

Copyright (C) 2009 Iain G. Mitchell QC.

This article is licensed under a Creative Commons UK (England and Wales) 2.0 licence, no derivative works, attribution, CC-BY-ND.

As a special exception, the author expressly permits faithful translations of the entire document into any language, provided that the resulting translation (which may include an attribution to the translator) is shared alike. This paragraph is part of the paper, and must be included when copying or translating the paper.

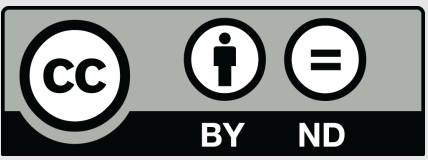

